OPEN ACCESS

Edited by:

Sheng Qin,

Jiangsu Normal University, China

Reviewed by:

Samina Mehnaz,

Forman Christian College, Pakistan

Salam Nimaichand,

Sun Yat-sen University, China

*Correspondence: Fatemeh Mohammadipanah fmohammadipanah@ut.ac.ir

Abdolvahab Maghsoudlou wahab@inio.ac.ir

Specialty section:

This article was submitted to

Extreme Microbiology,

a section of the journal

Frontiers in Microbiology

Received: 06 June 2018 Accepted: 04 December 2018

Published: 09 January 2019

Citation:

Heidarian S, Mohammadipanah F,

Maghsoudlou A, Dashti Y and

Challis GL (2019) Anti-microfouling Activity of Glycomyces sediminimaris UTMC 2460 on Dominant Fouling

Bacteria of Iran Marine Habitats.

Front. Microbiol. 9:3148.

doi: 10.3389/fmicb.2018.03148

\section{Anti-microfouling Activity of Glycomyces sediminimaris UTMC 2460 on Dominant Fouling Bacteria of Iran Marine Habitats}

\author{
Sheida Heidarian ${ }^{1}$, Fatemeh Mohammadipanah ${ }^{1 *}$, Abdolvahab Maghsoudlou²*, \\ Yousef Dashti ${ }^{3}$ and Gregory L. Challis ${ }^{3,4,5}$
}

1 Department of Microbiology, School of Biology and Center of Excellence in Phylogeny of Living Organisms, College of Science, University of Tehran, Tehran, Iran, ${ }^{2}$ Ocean Science Research Center, Iranian National Institute for Oceanography and Atmospheric Science, Tehran, Iran, ${ }^{3}$ Department of Chemistry, University of Warwick, Coventry, United Kingdom, ${ }^{4}$ Warwick Integrative Synthetic Biology Centre, University of Warwick. Coventry, United Kingdom, ${ }^{5}$ Department of Biochemistry and Molecular Biology, Monash University, Clayton, VIC, Australia

Discovery of environmentally safe anti-fouling agent is currently of considerable interest, due to the continuous impact of biofoulers on the marine habitats and the adverse effects of biocides on the environment. This study reports the anti-adhesion effect of marine living Actinobacteria against fouling strains isolated from submerged panels in marine environments of Iran. The extract of Glycomyces sediminimaris UTMC 2460 affected the biofilm formation of Kocuria sp. and Mesorhizobium sp., as the dominant fouling agents in this ecosystem, up to $93.2 \%$ and $71.4 \%$, respectively. The metabolic activity of the fouler bacteria was reduced by the extract up to 17 and $9 \%$, respectively. This indicated the bactericidal potency of the extract on cells in the biofilm state that enables the compound to be effective even once the biofilms are established in addition to the inhibition of biofilm initiation. Moreover, extra polymeric substance (EPS) production by fouling bacteria was reduced by $60-70 \%$. The absence of activities against fouling bacteria in suspension and also the absence of toxic effect on Artemia salina showed the harmless ecological effect of the anti-microfouling extract on the prokaryotic and eukaryotic microflora of the studied Iran marine ecosystem. Metabolic profiling of $\mathrm{G}$. sediminimaris UTMC 2460 revealed the presence of compounds with molecular formulae matching those of known anti-fouling diketopiperazines as major components of the extract. These results suggest that the extract of Glycomyces sediminimaris UTMC 2460 could be used as a potentially eco-friendly viable candidate in comparison to the synthetic common commercial anti-microfouling material to prevent the fouling process in marine habitats of Iran.

Keywords: surface microlayer, antifouling substances, fouling organisms, marine Actinobacteria, secondary metabolites, marine sediment

\section{INTRODUCTION}

Colonization and successive overgrowth of epibiotic organisms on submerged surfaces is a natural process, known as biofouling. It causes ecological and economic problems for water-immersed man-made structures and marine sectors such as the loss of productivity in aquaculture, toxicity and side effects of chemical anti-fouling treatments on non-target organisms 
(Thomas and Brooks, 2010), increased fuel costs for shipping, corrosion of metal pipes, ship and filtration system blockage; an increase in the weight of off-shore sea platforms, in addition to the costs associated with ongoing prevention and control (Garrett et al., 2008). Current anti-fouling strategies inhibit or eradicate the fouling organisms, by releasing high amounts of toxic chemicals into the environment. Therefore, compounds with high inhibitory performance and low side effects have a high priority for biofouling control.

The phenomenon of biofouling is preceded by biofilm formation. Microbial adhesion corresponding to the first stages of biofilm formation (microfouling) is a critical step in biofouling. Although the initial adhesion of microfoulers in primary steps is reversible and achieved by physical forces such as Brownian motion, gravity, and water flow, following the maturation of the biofilm their presence becomes permanent (Cao et al., 2011). Formation of slime layers comprising surfaceattached bacteria (mainly Proteobacteria) and their extracellular polymeric substances provide the prerequisite conditions for further attachment and increases the settlement of macrofouling organisms (Donlan and Costerton, 2002).

Detailed knowledge about biofilms is crucial for understanding and preventing biofouling. However, it is more practical to inhibit fouling formation at the initial phase. To discover non-toxic and eco-friendly benign anti-foulants, organisms such as typical free fouling organisms with natural chemical defense mechanisms have been investigated (Abarzua et al., 1999; Piazza et al., 2011; Dobretsov et al., 2013).

The most serious problem encountered in the development of derivatives of natural anti-fouling agents is producing large amounts of anti-fouling compounds using these organisms (Fusetani, 2011). To overcome this problem, other sources such as easily cultivable terrestrial and marine microorganisms including bacteria, fungi, and cyanobacteria have been explored in recent years (Qian et al., 2009). Among various habitats, marine environments provide great opportunity for discovery of novel bioactive compounds, due to intact, underexplored and highly bio-diverse ecosystems, compared to terrestrial environments.

The Persian Gulf's marine environment is characterized by environmental extremes due to its location and bathymetry (Sale et al., 2011). The extreme salinity and temperature fluctuations of the Persian Gulf waters, which is one of the semi-enclosed marine systems, have created unique marine ecosystems (Bayani, 2016).

The phylum Actinobacteria is extraordinarily diverse and widely distributed in the marine environment (Maldonado et al., 2005; Pathom-Aree et al., 2006). Due to their large genome size and proven ability to produce structurally and functionally novel bioactive compounds, they hold a prominent position in biotechnological industries as sources of substitutes for commercial synthetic materials (Subramani and Aalbersberg, 2013). Therefore, marine Actinobacteria are a rich source of novel and biologically active products, with the potential to impede the adhesion of fouling organisms on artificial or natural surfaces. Herein, we investigated new marine Actinobacteria as a potential source of eco-friendly metabolites with antimicrofouling activity.

\section{MATERIALS AND METHODS}

\section{Isolation of the Marine Microfouler Bacteria \\ Experimental Field for Biofilm Formation on Artificial Surfaces}

In order to isolate dominant fouling bacteria from the Oman sea, four different artificial substrates including wood, aluminum, steel and fiberglass were mounted on polyethylene holders and exposed to seawater at $4 \mathrm{~m}$ depth and left for 14 days at $31^{\circ} \mathrm{C}$ to form microfouling films. Each structure was collected after a 1-day interval and transferred to the laboratory under sterile conditions. Physicochemical parameters such as temperature, salinity, $\mathrm{pH}$ and dissolved oxygen of the water sample were also measured during the formation of films.

\section{Isolation of Initial Fouling Bacteria From Submerged Artificial Platforms}

Each panel was washed with sterile artificial seawater to rinse the loosely attached cells, mud, and clay. Surface-attached bacteria (biofilm slime samples) were obtained through swabbing and scraping surfaces of the material, using sterile cotton swabs and razors. Media including Vaatanen nine salt solution (VNSS), Zobella marine agar (ZMA), and nutrient agar were used to cultivate microfouling bacteria at the early stage of the fouling process. Plates were incubated at $28^{\circ} \mathrm{C}$ for 5 days in the dark. The morphologically distinct biofilm bacterial colonies were purified and stored at $8^{\circ} \mathrm{C}$ for further analysis.

\section{Assessment of Biofilm Formation by Crystal Violet Assay}

The ability of the prevalent microfouling bacteria in the Oman sea to form static biofilms was determined in 96 well flatbottom polystyrene microtiter plates (Biofil, China) as described (Stepanović et al., 2000). Each well of the microplates was filled with $300 \mu \mathrm{l}$ of the test bacterial inoculums in nutrient broth supplemented with $1 \%$ glucose and $1 \%$ sucrose with a cell density of 0.2 at $600 \mathrm{~nm}$, and incubated for $72 \mathrm{~h}$ at $37^{\circ} \mathrm{C}$. Culture medium and planktonic cells, as well as loosely adhered bacteria, were removed by dual washing with sterile physiological saline. Firmly attached bacteria firstly were fixed with $250 \mu$ l methanol for $15 \mathrm{~min}$, then stained with $250 \mu \mathrm{l}$ crystal violet $(0.05 \%$, $\mathrm{v} / \mathrm{v})$. After $15 \mathrm{~min}$, the stain was withdrawn and the wells were washed twice with sterile distilled water. Plates were air-dried at room temperature and the stain was ultimately solubilized by adding $250 \mu \mathrm{l}$ of glacial acetic acid (33\% v/v) for $15 \mathrm{~min}$ and its absorbance was recorded at $545 \mathrm{~nm}$. Growth medium was included for sterility check. Staphylococcus aureus UTMC 1403 was used as positive control. Experiments were run in triplicate.

\section{Selection of Optimum in vitro Condition for Biofilm Formation by Model Fouling Marine Bacteria}

The impact of additive sugars in enhancing biofilm formation of two potent fouling bacteria was investigated by adding different concentrations $(0.5$ and $1 \% \mathrm{v} / \mathrm{v})$ of three types of saccharide (glucose, sucrose, and fructose) alone and also in combined 
regimes. Then, glucose and sucrose $1 \%$ regimes as the biofilm formation enhancers were included in two different nutrient growth media of BHI broth (Merck, Germany) and nutrient broth (Merck, Germany) and the biofilm formation support of these two modified media were compared.

\section{Isolation of Marine Actinobacterial Strains}

\section{Sampling Sites and Sediment Samples Collection}

The sediment samples were collected using a grab sampler from different Iranian sites of the Persian Gulf and the Oman sea, from a depth of 8-70 m between December 2013 and September 2014. Sediment samples were placed in sterile plastic bags and transported with ice pieces to the lab and were stored at $8^{\circ} \mathrm{C}$ for further studies.

\section{Sample Preparation}

Samples were heated at $50^{\circ} \mathrm{C}$ for $72 \mathrm{~h}$ to select heatresistant spore-producing bacteria (including Actinobacteria) and decrease the colonization of unwanted fast-growing bacteria. Dried samples were then ground, sieved and transferred to sterilized falcon tubes for further analysis.

\section{Isolation Condition of Actinobacterial Strains}

Serial dilutions of $10^{-1}$ to $10^{-3}$ of each treated sediment sample were homogenized in $3 \%$ natural sea salt solution and $200 \mu \mathrm{l}$ of each sample was spread evenly on modified oligotrophic isolation media (Table 1). The isolation media were appended with Oman sea salt to select indigenous marine dwelling bacteria. Moreover, all media were prepared in $1 / 5$ diluted form to simulate the oligotrophic conditions of the marine ecosystem. Isolation of colonies was conducted from the 14th to the 28th day of incubation at $28^{\circ} \mathrm{C}$. Individual colonies observed on plates were subcultured on ISP2 agar medium (malt extract, $10 \mathrm{~g}$; yeast extract, 4 g; glucose, 4 g; calcium carbonate, 2 g; agar 14 g in 1 $\mathrm{L}$ of distilled water, $\mathrm{pH}$ 7.5) until pure colonies were obtained. Ultimately, purified isolates were stored at $-20^{\circ} \mathrm{C}$ in half strength ISP2 media containing 30\% glycerol for further studies.

\section{Fermentation and Extraction of Secondary Metabolites}

Bacterial precultures were prepared by inoculating patches $(1 \mathrm{~cm} \times 1 \mathrm{~cm})$ of well-grown colonies in $50 \mathrm{ml}$ ISP2 broth culture medium, followed by incubation at $28^{\circ} \mathrm{C}$ with shaking at $160 \mathrm{rpm}$ for $48 \mathrm{~h}$. The fermentation medium was then inoculated with 5\% of actively growing seed culture. After 7 days of incubation at $28^{\circ} \mathrm{C}$, extraction was performed by shaking with the same ratio of ethyl acetate for $1 \mathrm{~h}$, followed by supernatant separation using centrifugation at 4,000 rpm for $10 \mathrm{~min}$. The organic phase was evaporated to dryness and concentrated using a rotary evaporator (Heidolph, Germany) at $35^{\circ} \mathrm{C}$ to obtain the bacterial extract.

\section{Anti-adhesion Activity in Presence of Crude Extract}

To evaluate the inhibitory effect of the extracts on bacterial adhesion, $50 \mu \mathrm{l}$ of each crude extract dissolved in methanol to a final concentration of 100 and $300 \mu \mathrm{g} \mathrm{ml}^{-1}$ was added to each well. $250 \mu \mathrm{l}$ of fresh test bacterial cell suspension was then added to each well (final optical density of 0.2 at $600 \mathrm{~nm}$ ) in nutrient broth media supplemented with $1 \%$ glucose and $1 \%$ sucrose, and the resulting mixtures were incubated at $37^{\circ} \mathrm{C}$. After an optimal adherence time of $72 \mathrm{~h}$, non-adherent bacteria in the spent medium were removed and the wells were washed twice with physiological saline. Fixation and staining steps were performed in the same manner using the crystal violet assay. The relative rate of adhesion to the bottom of wells in the presence of crude extract was calculated using the following equation

TABLE 1 | The modified media used in isolation of marine-derived Actinobacteria from sediment samples.

\begin{tabular}{|c|c|c|}
\hline Medium & Components & Reference \\
\hline $\begin{array}{l}* 1 / 5 \text { Glycerol } \\
\text { asparagine agar (GA) }\end{array}$ & $\begin{array}{l}\text { Glycerol, } 2 \mathrm{~g} \text {; asparagine, } 0.5 \mathrm{~g} ; \mathrm{K}_{2} \mathrm{HPO}_{4}, 1 \mathrm{~g} ; \mathrm{NaCl}, 0.5 \mathrm{~g} ; \mathrm{MgSO}_{4} 7 \mathrm{H}_{2} \mathrm{O}, 0.5 \mathrm{~g} ; \mathrm{FeSO}_{4} 7 \mathrm{H}_{2} \mathrm{O}, 0.01 \mathrm{~g} ; \mathrm{CuSO}_{4} \text {, } \\
0.001 \mathrm{~g} ; \mathrm{MnSO}_{4}, 0.001 \mathrm{~g} ; \mathrm{ZnSO}_{4}, 0.001 \mathrm{~g} ; \text { Agar, } 14 \mathrm{~g} \text { and } 1 \mathrm{~L} \text { of seawater, } \mathrm{pH} 7.5\end{array}$ & Chen et al., 2012 \\
\hline $\begin{array}{l}\text { 1/5 Vaatanen } \\
\text { Nine-Salt Solution } \\
\text { (VNSS) }\end{array}$ & $\begin{array}{l}\text { Glucose, } 0.1 \mathrm{~g} \text {; peptone, } 0.2 \mathrm{~g} \text {; yeast extract, } 0.1 \mathrm{~g} \text {; soluble starch, } 1 \mathrm{~g} ; \mathrm{FeSO}_{4} 7 \mathrm{H}_{2} \mathrm{O}, 0.01 \mathrm{~g} ; \\
\mathrm{Na}_{2} \mathrm{HPO}_{4} \cdot 2 \mathrm{H}_{2} \mathrm{O}, 0.007 \mathrm{~g} \text {; sea salt, } 17.6 \mathrm{~g} ; \mathrm{Na}_{2} \mathrm{SO}_{4}, 1.47 \mathrm{~g} ; \mathrm{NaHCO}_{3}, 0.08 \mathrm{~g} ; \mathrm{KBr}, 0.04 \mathrm{~g} ; \mathrm{KCl}, 0.25 \mathrm{~g} ; \\
\mathrm{MgCl}_{2} \cdot 6 \mathrm{H}_{2} \mathrm{O}, 1.87 \mathrm{~g} ; \mathrm{CaCl}_{2} \cdot 2 \mathrm{H}_{2} \mathrm{O}, 0.41 \mathrm{~g} ; \mathrm{SrCl}_{2} \cdot 6 \mathrm{H}_{2} \mathrm{O}, 0.01 \mathrm{~g} ; \mathrm{H}_{3} \mathrm{BO}_{3}, 0.01 \mathrm{~g} \text {; agar, } 14 \mathrm{~g} \text { and } 1 \mathrm{~L} \text { of } \\
\text { distilled water, pH } 7.5\end{array}$ & Heindl et al., 2012 \\
\hline $\begin{array}{l}1 / 5 \text { "Reasoner's } 2 \mathrm{~A} \\
(\mathrm{R} 2 \mathrm{~A})\end{array}$ & $\begin{array}{l}\text { Yeast extract, } 0.1 \mathrm{~g} \text {; bacteriologic peptone, } 0.1 \mathrm{~g} \text {; casein hydrolysate, } 0.1 \mathrm{~g} \text {; glucose, } 0.1 \mathrm{~g} \text {; soluble starch, } \\
0.1 \mathrm{~g} \text {; sodium pyruvate, } 0.06 \mathrm{~g} \text {; agar, } 14 \mathrm{~g} \text { and } 1 \mathrm{~L} \text { of seawater, } \mathrm{pH} 7.2-7.4\end{array}$ & Heindl et al., 2012 \\
\hline $\begin{array}{l}\text { Modified HV agar } \\
\text { (Natural sea water) }\end{array}$ & $\begin{array}{l}\text { Fish powder, } 0.1 \mathrm{~g} ; \mathrm{CaCO}_{3}, 0.02 \mathrm{~g} ; \mathrm{Na}_{2} \mathrm{HPO}_{4}, 0.5 \mathrm{~g} ; \mathrm{MgSO}_{4} .7 \mathrm{H}_{2} \mathrm{O}, 0.5 \mathrm{~g} ; \mathrm{KCl}, 1.7 \mathrm{~g} ; \mathrm{FeSO}_{4} .7 \mathrm{H}_{2} \mathrm{O}, 0.01 \mathrm{~g} ; \\
\text { Vitamin solution, } 1 \mathrm{ml} \text {; agar, } 14 \mathrm{~g} ; 1 \mathrm{~L} \text { of sea water, } \mathrm{pH} \text { 7-7.5 } \\
\text { Vitamin solution consist of (biotin, } 200 \mathrm{mg} \text {; pyridoxine } \mathrm{HCl}, 500 \mathrm{mg} \text {; thiamine } \mathrm{HCl}, 500 \mathrm{mg} \text {; riboflavin, } 1 \mathrm{~g} ; \\
\text { nicotinamide, } 1 \mathrm{~g} \text {; P-aminobenzoic acid, } 100 \mathrm{mg} 1 \mathrm{~L} \text { of distilled water }\end{array}$ & Sharma, 2014 \\
\hline $\begin{array}{l}\text { Modified HV agar } \\
\text { (Soil extract) }\end{array}$ & $\begin{array}{l}\text { Fish powder, } 0.1 \mathrm{~g} ; \mathrm{CaCO}_{3}, 0.02 \mathrm{~g} ; \mathrm{Na}_{2} \mathrm{HPO}_{4}, 0.5 \mathrm{~g} ; \mathrm{MgSO}_{4} .7 \mathrm{H}_{2} \mathrm{O}, 0.5 \mathrm{~g} ; \mathrm{KCl}, 1.7 \mathrm{~g} ; \mathrm{FeSO}_{4} .7 \mathrm{H}_{2} \mathrm{O}, 0.01 \mathrm{~g} \\
\text { Vitamin solution, } 1 \mathrm{ml} \text {; agar, } 14 \mathrm{~g} ; 1 \mathrm{~L} \text { of soil extract, } \mathrm{pH} 7-7.5\end{array}$ & $\begin{array}{l}\text { Ramesh and } \\
\text { Mathivanan, } 2009\end{array}$ \\
\hline $\begin{array}{l}\text { Modified Zobella } \\
\text { marine agar }\end{array}$ & $\begin{array}{l}\text { Peptic digest of animal tissue extract, } 30 \mathrm{ml} \text {; yeast extract, } 1 \mathrm{~g} \text {; ferric citrate, } 0.1 \mathrm{~g} ; \mathrm{NaCl}, 19.45 \mathrm{~g} ; \mathrm{MgCl}_{2}, 8.8 \mathrm{~g} \text {; } \\
\mathrm{Na}_{2} \mathrm{SO}_{4}, 3.240 \mathrm{~g} \text {; sea salt, } 1.8 \mathrm{~g} ; \mathrm{KCl}, 0.55 \mathrm{~g} ; \mathrm{NaHCO}_{3}, 0.16 \mathrm{~g} ; \mathrm{KBr}, 0.08 \mathrm{~g} ; \mathrm{SrCl}_{2}, 0.034 \mathrm{~g} \text {; boric acid, } \\
0.022 \mathrm{~g} ; \mathrm{NH}_{4} \mathrm{NO}_{3}, 0.0016 \mathrm{~g} ; \mathrm{Na}_{2} \mathrm{HPO}_{4}, 0.008 \mathrm{~g} \text {; sodium silicate, } 0.004 \mathrm{~g} \text {; sodium fluorate, } 0.0024 \mathrm{~g} \text {; agar, } \\
14 \mathrm{~g} ; 1 \mathrm{~L} \text { of distilled water, } \mathrm{pH} 7.2+0.2\end{array}$ & Satheesh et al., 2012 \\
\hline
\end{tabular}

*All media are prepared in one-fifth diluted form. 
(Bakkiyaraj and Karutha Pandian, 2010).

$$
\text { Adhesion }(\%)=\frac{(\text { Control OD }- \text { Treated OD })}{\text { Control OD }} \times 100
$$

Microtiter wells containing bacterial cell suspension in nutrient broth medium without added extract were used as bacterial adhesion controls. In addition, the maximum percentage of methanol used for dilution of extracts and sterile nutrient broth medium was used as negative controls. Diuron (Sigma-Aldrich, United States), which is a commercially available anti-fouling agent, was used as a positive control $\left(1\right.$ and $\left.10 \mu \mathrm{g} \mathrm{ml}^{-1}\right)$.

\section{Quantification of Extra Polymeric Substance (EPS) Content for Potent Biofilm-Forming Bacteria}

Determination of EPS content of the selected marine fouling bacteria in the presence and absence of the extract at concentrations of 100 and $300 \mu \mathrm{g} \mathrm{ml}^{-1}$ was conducted by using the total carbohydrate assay, as follows. The culture broth from $72 \mathrm{~h}$ cultures of each microfouling bacterium was centrifuged at $14,000 \times g$ and $4^{\circ} \mathrm{C}$ for $15 \mathrm{~min}$ to obtain the culture supernatant. The supernatant was passed through a $0.2 \mu \mathrm{m}$ filter and the filtrate was mixed with ethanol at a ratio of 1:3, then left to precipitate at $4^{\circ} \mathrm{C}$ overnight. Settled EPS was collected by centrifugation at $10,000 \times g$ and $25^{\circ} \mathrm{C}$ for $5 \mathrm{~min}$, then dissolved in PBS and the concentrations of carbohydrates were determined with the modified phenol-sulphuric acid method using glucose as the standard (DuBois et al., 1956).

\section{Anti-bacterial Activities of the Anti-microfouling Extract Against the Marine Biofilm Forming Strains}

The most effective extract with biofilm inhibition activity was evaluated for its inhibitory effect on marine biofilm forming bacteria using the agar disk diffusion method as described by Kirby-Bauer (Hudzicki, 2009). Firstly, $20 \mu \mathrm{l}$ of the extract stock solution in $1 \mathrm{ml}$ of methanol was applied on a sterile disk and allowed to dry such that the final concentrations on each disk were 5, 15, and $100 \mu \mathrm{g} \mathrm{ml}^{-1}$. The nutrient agar plates were seeded by spreading $100 \mu \mathrm{l}$ of each test cell suspension (cell density of 0.2 at $600 \mathrm{~nm}$ ), onto which the disks were placed and incubated at $35^{\circ} \mathrm{C}$ for $24 \mathrm{~h}$. Standard antibiotic-containing disks [cefotaxime $(30 \mu \mathrm{g})$, imipenem $(10 \mu \mathrm{g})$, and ticarcillin $(20 \mu \mathrm{g})$ ] and filter paper disks soaked in methanol were used as positive and negative controls, respectively. Anti-microbial efficacy was determined by measuring the growth inhibition zone around the disks after $24 \mathrm{~h}$.

\section{Bacteriostatic and Bactericidal Activity of Anti-microfouling Extracts}

The minimum inhibition concentration value of the effective extract with the highest anti-adhesion and anti-bacterial activity was determined by the microdilution method following the CLSI procedure (Wayne, 2017). Briefly, $20 \mu \mathrm{l}$ of each microfouling strain suspension with a cell density of 0.2 at $600 \mathrm{~nm}$ was added to each well containing extract at concentrations of 6.25-400 $\mu \mathrm{g} \mathrm{ml}^{-1}$, along with an appropriate growth medium. Ciprofloxacin $\left(0.25,0.5,1,2\right.$, and $\left.4 \mu \mathrm{g} \mathrm{ml}^{-1}\right)$ was used as a positive control and well plates containing only bacterial suspensions were considered as the negative control. Following incubation at $35^{\circ} \mathrm{C}$ for $24 \mathrm{~h}$, the lowest concentration at which the bacterial growth was inhibited and the one at which there was no visible bacterial growth on the agar plate was recorded as the MIC and MBC values, respectively.

\section{Quantification of Microfouler Metabolic Activity in Presence of Anti-microfouling Extract}

The XTT [2,3-bis(2-methoxy-4-nitro-5-sulfophenyl)-2Htetrazolium-5-carboxanilide] reduction assay was used to determine the bactericidal effects of the extract on single species biofilm populations as described (Padmavathi et al., 2014) with minor modifications. After biofilm formation of the tested bacteria in nutrient broth medium, the cell density was adjusted to 0.2 at $600 \mathrm{~nm}$ and combined with $50 \mu \mathrm{l}$ extract solution to provide final concentrations of 50,100, 200, and $300 \mu \mathrm{g} \mathrm{ml}^{-1}$ in a total volume of $300 \mu \mathrm{l}$ per well. The wells were washed twice with $300 \mu \mathrm{l}$ of sterile physiological saline. Then biofilms were incubated with $200 \mu \mathrm{l}$ of XTT solution containing $150 \mathrm{mg}$ XTT and $10 \mathrm{mg}$ of phenazine methosulfate (Sigma-Aldrich) for $6 \mathrm{~h}$ in the dark, at $37^{\circ} \mathrm{C}$ at $120 \mathrm{rpm}$. The absorbance due to the formazan formed was measured at $490 \mathrm{~nm}$ using a MRP4+ microplate reader (Hyperion, England). Ciprofloxacin (2 and $4 \mu \mathrm{g} \mathrm{ml}^{-1}$ ) was used as a positive bactericidal reference. Wells containing plain culture medium without biofilms were used as blanks and biofilm containing wells without extracts were used as negative controls. The results were expressed as a percentage of inhibited activity.

\section{Eukaryotic Cell Toxicity Assay}

Brine shrimp Artemia salina larvae were used as a model for detecting the toxicity of the extract. The anti-crustacean assay was performed in 24 well clear polystyrene plates (Meyer et al., 1982) in artificial seawater (3\%) as the hatching solution. The extract was added at different concentrations $\left(5,10,20 \mu \mathrm{g} \mathrm{ml}^{-1}\right)$ and incubated at $25^{\circ} \mathrm{C}$ in the dark with $15-20$ larvae in each well. Artificial seawater containing $1 \%$ DMSO and potassium dichromate solution $(0.5 \mathrm{M})$, were used as the negative and positive controls, respectively. The Mortality rate was calculated after $24 \mathrm{~h}$ according to the following formula:

$$
M=\frac{A-B-N}{G-N} \times N-0 \quad \text { Viability }=100 \times(1-M)
$$

Where $A=$ dead larvae number after $24 \mathrm{~h}, N=$ dead larvae number initially, $M=$ dead larvae percentage after $24 \mathrm{~h}, G=$ total number of larvae, and $B=$ average number of dead larvae in negative control after $24 \mathrm{~h}$.

\section{Hemolytic Activity Assay}

The lytic activity of the extract was measured against human red blood cells. The red blood cells (10\%) were separated by 
centrifugation at 3,500 rpm for $15 \mathrm{~min}$ and washed with PBS buffer three times. The most potent biofilm inhibiting extract was prepared at final concentrations of 50, 100, 200, 300, $400 \mu \mathrm{g} \mathrm{ml}^{-1}$ and added to the red cell suspension in PBS buffer. Mixtures of blood and extract were incubated at $37^{\circ} \mathrm{C}$ for $1 \mathrm{~h}$. The supernatants were collected by centrifugation at 2,500 rpm for $5 \mathrm{~min}$ and optical densities were measured at $545 \mathrm{~nm}$. Ferrous sulfate solution at a concentration of $65 \mathrm{mM}$ was used as a positive control.

\section{Evaluation of Anti-microfouling Activity of the Actinobacterial Extracts in Field Experiments}

The anti-adhesion activity of the extracts on two dominant fouling bacteria of the ecosystem was tested in field conditions following a modification of a literature method (Schwartz et al., 2017). Gels were prepared by adding $0.75 \mathrm{~g}$ of Gelrite ${ }^{\circledR}$ (Dokhefa, Poland) to $50 \mathrm{ml}$ of distilled water and the $\mathrm{pH}$ was adjusted to 7.1. The mixture was sterilized and then cooled to $70^{\circ} \mathrm{C}$. Extracts were added to the liquid gel solution at a final concentration of 100 $\mu \mathrm{g} \mathrm{ml}^{-1}$ and poured into sterile 48 -well flat-bottom polystyrene microtiter plates. The same amount of methanol alone was added to Gelrite in the negative control well and Diuron (1 $\mu \mathrm{g} \mathrm{m}^{-1}$ ) was used as a positive control. Bacterial strains were grown on nutrient broth supplemented with $1 \%$ glucose and $1 \%$ sucrose at $28^{\circ} \mathrm{C}$ and $120 \mathrm{rpm}$. The cells were collected once stationary phase had been reached. After centrifugation, cells were suspended in sterile artificial seawater at an optical density of 0.5 at $600 \mathrm{~nm}$. Wells were seeded using $1 \mathrm{ml}$ of fouling bacterial suspension and the resulting cultures were grown for 7 days at $32^{\circ} \mathrm{C}$. Non-adherent bacteria were removed and the adhering bacteria were washed twice using physiological saline. The attached bacteria were moved from the gel surface into aqueous solution by sonicating at $40 \mathrm{KHz}$ for 1 min using Elmasonic P sonicator (Elma, Germany). Finally, the adhesion rate of attached bacteria on the gel surface $(n=3)$ of each treatment and control were quantified spectrophotometrically at $600 \mathrm{~nm}$.

\section{Characterization and Identification of Actinobacterium With Anti-microfouling Activity}

The potent anti-adhesion producing strain was characterized using morphological, physiological, and molecular approaches.

\section{Morphological Identification}

Cultural characteristics based on observation of macromorphology of the strain grown on ISP2 medium after incubation at $28^{\circ} \mathrm{C}$ for 14 days were recorded. Furthermore, the spore-bearing hypha and spore chains were directly examined using bacteria grown on ISP2 medium using the cover-slip technique and a Zeiss Merlin field emission scanning electron microscope (SEM), applying the SEM Smart software version 5.05 .

\section{Biochemical and Physiological Characteristics}

Physiological characteristics, including decomposition of xenobiotics, enzyme activity, and utilization of different sole carbon and nitrogen sources were determined as described (Goodfellow et al., 2012; Stackebrandt, 2014). Growth at different temperatures $\left(15,28,37\right.$, and $\left.42^{\circ} \mathrm{C}\right)$, and $\mathrm{pH}$ values $(4.0-12.0$ at intervals of $2 \mathrm{pH}$ units), and $\mathrm{NaCl}$ tolerance at concentrations ranging from 0 to $10 \%$ with intervals of $2.5 \% \mathrm{NaCl}(\mathrm{w} / \mathrm{v})$ were assessed after incubation at $28^{\circ} \mathrm{C}$ for $7-14$ days on ISP2 medium. In addition, the chemotaxonomic marker diaminopimelic acid (DAP) in cell wall hydrolysates was analyzed using the thin layer chromatography (Staneck and Roberts, 1974).

\section{Molecular Identification of the Most Potent Anti-microfouling Actinobacteria and Selected Dominant Biofilm Forming Bacterial Strains}

The 16S rRNA genes were amplified using a set of universal primers (Supplementary Table 1). Amplified chromosomal DNA obtained from PCR reactions was purified using a PCR purification kit (NucleoSpin ${ }^{\circledR}$ Gel and PCR Clean-up). The 16S rRNA gene sequences were blasted against the EzBioCloud database (Yoon et al., 2017).

\section{Metabolic Profiling of the Most Potent Strain With Anti-microfouling Activity}

The identification of specialized metabolites in the extract of Glycomyces sediminimaris UTMC 2460 was performed using a UHPLC-ESI-Q-TOF instrument with the following specifications: a Dionex UltiMate 3000 UHPLC connected to a Zorbax Eclipse Plus C18 column $(100 \times 2.1 \mathrm{~mm}, 1.8 \mu \mathrm{m})$ coupled to a Bruker MaXis IMPACT mass spectrometer. The mass spectrometer was operated in positive ion mode with a scan range of $50-3,000 \mathrm{~m} / z$. The solvent system of water (A)acetonitrile (B), each supplemented with $0.1 \%$ formic acid, was used for chromatography. A gradient of $5-100 \%$ B over $30 \mathrm{~min}$ was applied at a flow rate of $0.2 \mathrm{~mL} \mathrm{~min}^{-1}$. Calibration was performed with $1 \mathrm{mM}$ sodium formate at the start of each run.

\section{RESULTS}

\section{Isolation of Marine Fouling Bacteria From Submerged Platforms in Oman Sea}

Marine fouling bacteria of the region were isolated from biofilms or microfouling shaped on four types of immersed panels. A slime layer was visually observed on the submerged surfaces from $24 \mathrm{~h}$ and reached approximate $99 \%$ coverage in the second week of the immersion. Among various apparent colonies on three different nutritious media, four prevalent macro-morphological strain types were selected based on repetition on different platforms and successive detection on the isolation medium. Microscopic and macroscopic images of the prevalent initiators of the fouling phenomena in the Oman sea are shown in Table 2. 
TABLE 2 | Microscopic and macroscopic characteristic of the dominant marine biofilm bacteria obtained from Oman sea.

\begin{tabular}{|c|c|c|c|}
\hline Strain & Macroscopic image & Microscopic image & Artificial surface types \\
\hline Psychrobacter sp. UTMC 2516 & & & Woody panel \\
\hline Bacillus sp. UTMC 2517 & & & Steel panel \\
\hline Kocuria sp. UTMC 2449 & & & Fiberglass panel \\
\hline Mesorhizobium sp. UTMC 2518 & & & Aluminum panel \\
\hline
\end{tabular}

\section{Biofilm Forming Ability of the Selected Fouling Bacteria}

The biofilm formation intensity of the isolated fouling strains was evaluated via the crystal-violet colorimetric assay. To compensate for background absorbance, the OD of the sterile medium with fixative and dye was recorded and subtracted from the results. The absorbance values of the crystal-violet served as an indicator of the total biomass of attached bacteria at the bottom of microplate wells. Bacterial strains didn't show significant differentiation in biofilm formation ability at a low inoculum concentration $(5 \mu \mathrm{l})$, while their ability to form biofilms varied at higher levels of inoculation (15 and $50 \mu \mathrm{l}$ ). Among four dominant fouling bacteria, two strains of Kocuria sp. UTMC 2449 and Mesorhizobium sp. UTMC 2518 showed the highest biofilm formation ability, which corresponded to an increase in optical density up to 0.7 at $600 \mathrm{~nm}$ (Figure 1). These two strains were selected as the primary fouling bacteria and used as the test microfoulers in further experiments. In this experiment Staphylococcus aureus UTMC 1403 was used as positive control strain due to its strong ability to form biofilms.

\section{Optimum in vitro Conditions for Biofilm Formation of Main Fouling Bacteria}

The effects of growth medium supplementation with glucose, sucrose, and fructose were evaluated on the enhancement of biofilm formation by fouling bacteria. The results indicate that glucose and sucrose were more efficient sugars in comparison to fructose (Supplementary Figure 1), and the combination of glucose and sucrose $1 \%$ was more effective in the formation of the biofilm than each of them alone (Supplementary Figure 2). In addition, there was no significant difference between BHI and nutrient broth medium supplemented with $1 \%$ glucose and sucrose (Supplementary Figure 3). Hence, nutrient broth medium supplemented with $1 \%$ glucose and sucrose was selected as the medium supporting biofilm formation by Kocuria sp. UTMC 2449 and Mesorhizobium sp. UTMC 2518 for in vitro growth.

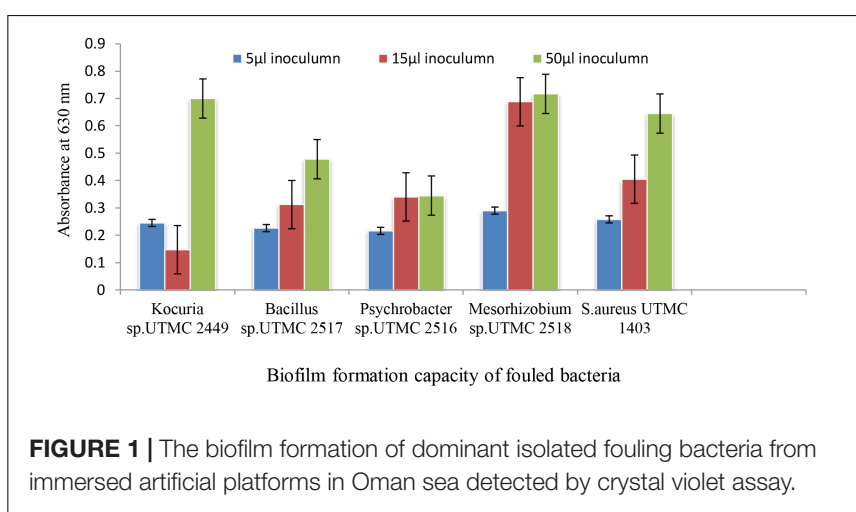




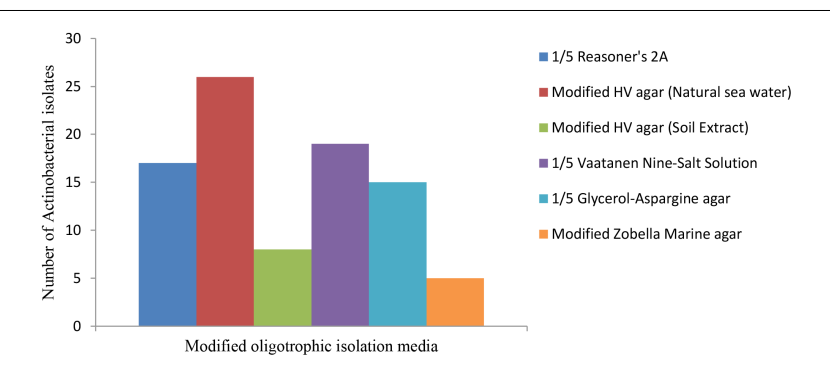

FIGURE 2 | Comparison of the isolation media versus the number of recovered strains. Modified $\mathrm{HV}$ medium containing artificial seawater supported the highest number and diversity of the Actinobacteria.

\section{Sediment Sample Collection and Isolation of Marine Actinobacteria}

A total of 50 sediment samples were collected from different sites between December 2013 and August 2014. The seawater physicochemical conditions at the test site were recorded. The average temperature, salinity level, $\mathrm{pH}$ and dissolved oxygen level at the sampling site were $32^{\circ} \mathrm{C}, 27.72 \mathrm{psu}, 7.15$ and $7.12 \mu \mathrm{mol}$ $1^{-1}$, respectively. A total of 90 strains were isolated from five oligotrophic isolation media. Modified HV medium containing artificial seawater provided the highest number and diversity of recovered strains with the minimum contaminants, followed by 1/5 Vaatanen Nine-Salt Solution and 1/5 R 2A (Figure 2).

\section{Production and Extraction of Metabolites From Marine Actinobacterial Strains}

Among a total of 90 isolated actinobacterial strains from the sediment samples, 10 morphologically distinct isolates were selected for evaluation of the anti-microfouling activity of their metabolite extracts. Concentrated crude extracts were preserved in the University of Tehran bio-compound Collection.

\section{Anti-adhesion Activity of the Extracts}

The ability of the selected marine actinobacterial extracts to attenuate biofilm formation by potent fouler bacteria from the Oman sea (Kocuria sp. and Mesorhizobium sp.) is shown in Figures 3A,B. The final results are expressed as the percentage of the reduction of adhered cells compared to a control that was not exposed to the extracts. Extracts with the highest anti-adhesion property at low concentration were selected for further analysis. All five initially selected extracts showed a concentration-dependent decrease in biofilm formation with the maximum biofilm inhibition activity at the lowest concentration value of $100 \mu \mathrm{g} \mathrm{ml}^{-1}$. The selected extracts caused $18-91 \%$ and $21-71 \%$ reduction in biofilm biomass production by Kocuria sp. UTMC 2449 and Mesorhizobium sp. UTMC 2518, respectively, at the minimum concentration of $100 \mu \mathrm{g} \mathrm{ml}^{-1}$. Most of the extracts exhibited stronger biofilm formation suppression against both fouling bacteria at the higher concentration of $300 \mu \mathrm{g}$ $\mathrm{ml}^{-1}$, as shown in Figures 3A,B. Among five potent extracts, the extract from Glycomyces sp. UTMC 2460 showed the maximum anti-adherence activity against the fouling bacteria.

\section{Effect of Bacterial Extract on EPS Production of Microfouling Bacteria}

A considerable decrease in EPS production by fouling bacteria in the presence of the extract from Glycomyces sp. UTMC 2460 was detected. The carbohydrate concentrations of the EPS extracted from Kocuria sp. UTMC 2449 suspensions were $92.19 \mu \mathrm{g} \mathrm{ml}^{-1}$ and $62.05 \mu \mathrm{g} \mathrm{m} l^{-1}$ in the presence of 100 and $300 \mu \mathrm{g} \mathrm{ml}^{-1}$ of the extract, respectively, while those in EPS isolated from Mesorhizobium sp. UTMC 2518 were 52.15 and $55.32 \mu \mathrm{g} \mathrm{ml}^{-1}$, respectively. The maximum reduction in EPS production (approximately 70\%) was observed in Kocuria sp. UTMC 2449 in the presence of crude extract (Figure 4). The extract could diminish the EPS production in fouling bacteria (62-73\%) with a similar efficiency of 1 and $10 \mu \mathrm{g} \mathrm{ml}^{-1}$ diuron on Mesorhizobium sp. and Kocuria sp., respectively.

\section{Antibacterial Effect of the Extract Against Main Fouling Bacteria}

The antibacterial activity of the extract against the pelagic form of fouling bacteria was investigated due to its probable effect on the balance of the ecosystem. The zone of inhibition produced by the extract from Glycomyces sp. UTMC 2460 against Kocuria sp. UTMC 2449 at concentrations of 15 and 100 $\mu \mathrm{g} \mathrm{ml}^{-1}$ was $3 \mathrm{~mm}$ and $8 \mathrm{~mm}$, respectively (Supplementary Figure 4). No anti-bacterial activity for the extract was detected against Mesorhizobium sp. UTMC 2518 at concentrations up to $100 \mu \mathrm{g} \mathrm{ml}^{-1}$.

\section{Determination of the MIC and MBC Values of the Glycomyces sp. Extract}

The minimal inhibitory concentration (MIC) and minimal bactericidal concentration (MBC) of the extract from Glycomyces sp. UTMC 2460 were determined for the fouler strains. The extract did not show growth inhibitory activity on fouling bacteria at concentrations less than $400 \mu \mathrm{g} \mathrm{ml}^{-1}$ and in fact the extract could not inhibit the fouler strains at low concentrations which has its anti-fouling effect. $100 \%$ bacteriostatic activity of the positive control against Kocuria sp. and Mesorhizobium sp. was exhibited at a concentration of $1 \mu \mathrm{g} \mathrm{ml} \mathrm{m}^{-1}$ for ciprofloxacin. The MBC value for ciprofloxacin was $2 \mu \mathrm{g} \mathrm{ml}^{-1}$. The Glycomyces sp. UTMC 2460 extract shows no bactericidal activity against two potent fouler bacteria in the planktonic phase.

\section{Bactericidal Effect of the Most Potent Extract Against the Fouling Bacteria in the Biofilm State}

An XTT reagent incubation time of $6 \mathrm{~h}$ was found to be optimal since the color intensity did not change further after this period (data not shown). Evaluation of the viability and metabolic activity of Kocuria sp. UTMC 2449 and Mesorhizobium sp. UTMC 2518 in the presence of the Glycomyces sp. extract in the biofilm state revealed that Kocuria sp. UTMC 2449 was more susceptible to the extract at the concentration examined. 

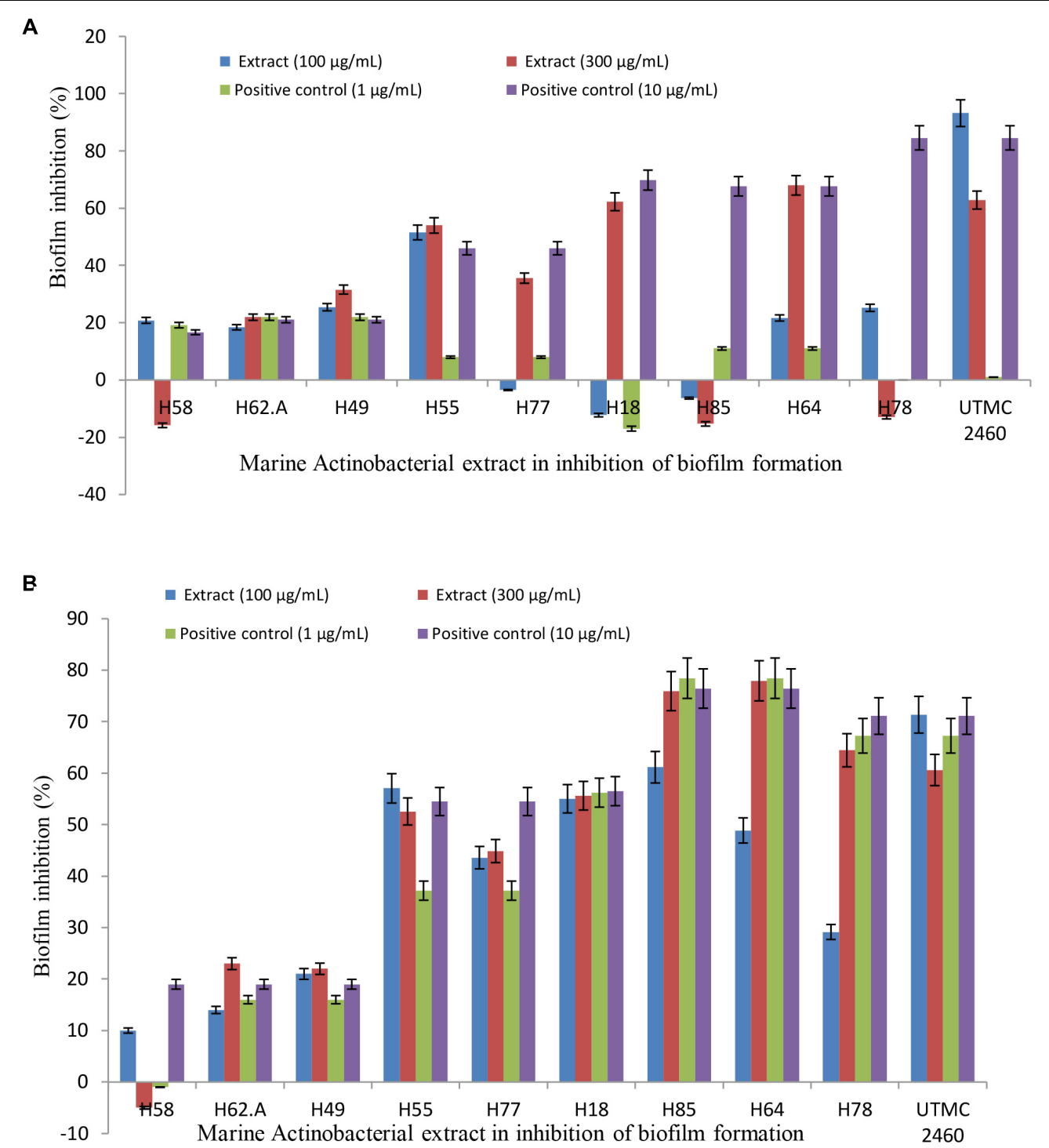

FIGURE 3 | Anti-adherence activity of Glycomyces sp. UTMC 2460 metabolite against dominant marine fouled bacteria. The graph illustrating the potential of selected marine Actinobacterial extracts (100 and $300 \mu \mathrm{g} \mathrm{ml}^{-1}$ ) on the adhesion prevention of marine fouling bacteria: (A) Kocuria sp. UTMC 2449 and (B) Mesorhizobium sp. UTMC 2518 in crystal violet assay.

The metabolic activity at the minimum biofilm inhibition concentration of the extract $\left(100 \mu \mathrm{g} \mathrm{ml}^{-1}\right)$ reduced by up to $17 \%$ and $9 \%$, respectively (Figure 5), after $6 \mathrm{~h}$ incubation with XTT reagent. The bactericidal effect of the extract was observed during the early phase of growth, with a 1.23 and $0.95 \mathrm{log}$ reduction for Kocuria sp. UTMC 2449 and Mesorhizobium sp. UTMC 2518, respectively. Furthermore, Kocuria sp. UTMC 2449 and Mesorhizobium sp. UTMC 2518 biofilms subjected to the positive control presented 1.43 and $1.17 \log$ metabolic reduction, respectively.

\section{Cytotoxicity Effect}

The anti-crustacean assay provides an indication of the ecological safety of the anti-microfouling extracts. From the results obtained, it was inferred that all extracts expressing high antibiofilm activity were not toxic toward Artemia salina larvae, because all exposed larvae were alive and motile after $24 \mathrm{~h}$ of incubation.

\section{Hemolytic Activity of the Glycomyces Extract}

The extract from the strain Glycomyces sp. UTMC 2460 had almost no or minimal (up to $8.8 \%$ ) lytic effect at concentrations of 50,100, and $200 \mu \mathrm{g} \mathrm{ml}^{-1}$ on human red blood cells (Figure 6). The biological safety of the most potent extract was inferred from its non-toxic effect on the blood cells. At the high concentrations of the extract (300 and $400 \mu \mathrm{g} \mathrm{ml}^{-1}$ ) toxicity was observed, presumably due to minor components of the extract. 


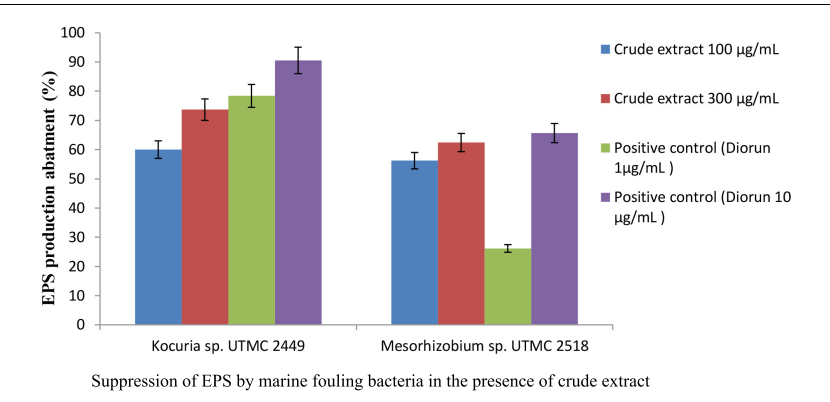

FIGURE 4 | Inhibitory effect of Glycomyces sp. UTMC 2460 extract on EPS production of fouling bacteria. Respective samples incorporated with "Diorun" (1 and $10 \mu \mathrm{g} \mathrm{ml}^{-1}$ ) serve as controls.

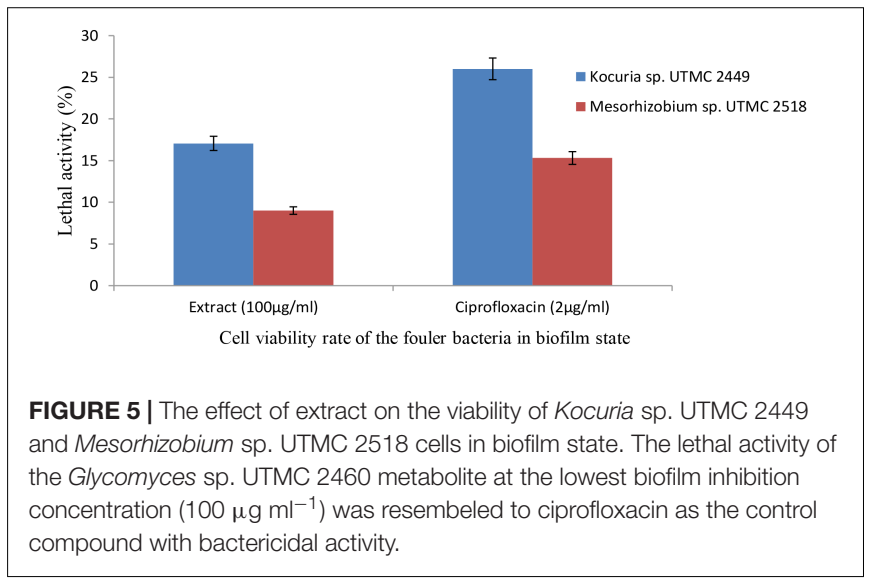

\section{Anti-microfouling Activity of the Crude Extract in Simulated Field Conditions}

The effect of the Glycomyces extract on the adhesion of fouling bacteria was investigated using in vitro conditions that mimic the natural conditions of the Oman sea in terms of $\mathrm{pH}$, salinity and temperature. The cell density of Kocuria sp. UTMC 2449 on the gels in the presence of the extract and in the positive control did not differ from each other and cell attachment was reduced up to $37 \%$. The extract exhibited lower suppression of the adhesion of Mesorhizobium sp. UTMC 2518 (31\%) than Diuron $\left(1 \mu \mathrm{g} \mathrm{ml}^{-1}\right)$. While the positive control showed a higher inhibitory effect on Mesorhizobium sp. UTMC 2518 (43\%) than Kocuria sp. UTMC 2449 (36\%) (Figure 7), the converse was observed for the extract.

\section{Molecular Identification of the Most Prevalent Marine Fouling Bacteria From Artificial Platforms}

Results obtained from BLAST analyses of the 16S rRNA sequences from the fouling isolates against the GenBank and EzBioCloud databases showed that they belong to four genera, including Psychrobacter, Kocuria, Bacillus and Mesorhizobium (Table 3). These sequences were deposited in the GenBank database under the accession numbers shown in Table 3.

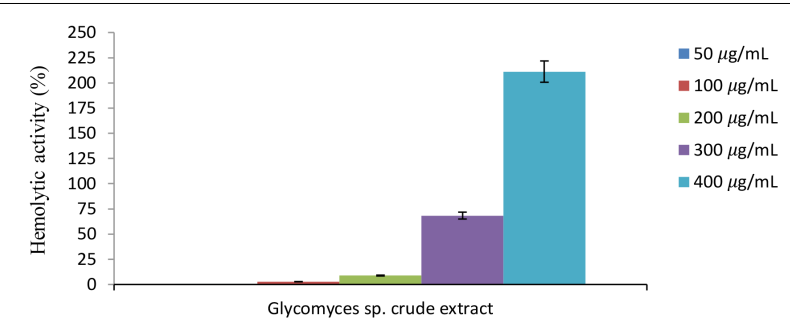

Human red blood cell lysis in the presence of extract

FIGURE 6 | Hemolytic activity of Glycomyces sp. UTMC 2460 crude extract on human red blood cell. Almost no or a low hemolytic effect was detected at low concentrations of the extract $\left(50,100\right.$, and $\left.200 \mu \mathrm{g} \mathrm{ml}^{-1}\right)$. Hemolysis activity was evaluated in comparison to $\mathrm{FeSO}_{4}$ solution $(65 \mathrm{mM})$ as a positive control.

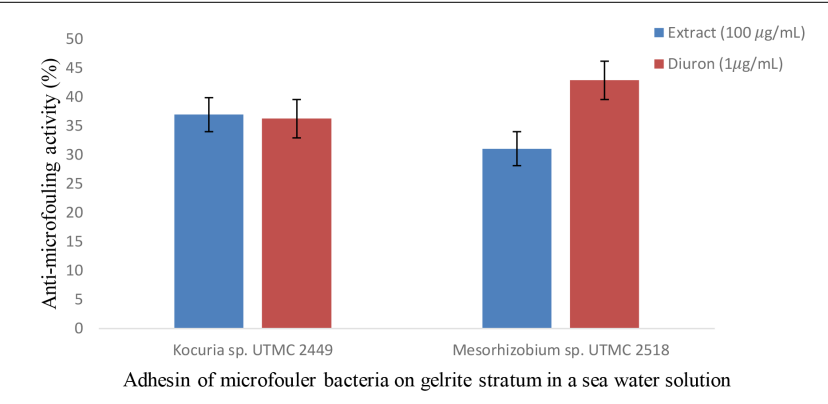

FIGURE 7 | Anti-microfouling activity of Glycomyces sp. UTMC 2460 crude extract on two fouler bacteria in a simulated field condition. The extract exhibited $31 \%$ and $37 \%$ microfouling inhibition activity against Mesorhizobium sp. UTMC 2518 and Kocuria sp. UTMC 2449, respectively, in a mimicked field condition at in vitro experiment.

TABLE 3 | Molecular identification of marine fouling bacteria based on $16 \mathrm{~S}$ rRNA sequence.

\begin{tabular}{llll}
\hline $\begin{array}{l}\text { UTMC } \\
\text { number }\end{array}$ & Strain name & Similarity (\%) & $\begin{array}{c}\text { Accession } \\
\text { number }\end{array}$ \\
\hline 2449 & Kocuria sp. & Kocuria atrinae 99\% & $\mathrm{MH} 201002$ \\
2516 & Psychrobacter sp. & Psychrobacter faecalis 95.5\% & $\mathrm{MH} 201003$ \\
2517 & Bacillus sp. & Bacillus atrophaeus 99.8\% & $\mathrm{MH} 201004$ \\
2518 & Mesorhizobium sp. & Mesorhizobium amorphae 98.5\% & $\mathrm{MH} 201005$
\end{tabular}

\section{Polyphasic Identification of the Strain Producing the Anti-microfouling Activity}

Observation under a microscope indicated that the strain was Gram-positive with branching substrate mycelium and thus belongs to the phylum Actinobacteria (Figure 8B). Rod-like spores on aerial sporophores were observed under scanning electron microscopy (Figure 8A) and the strain formed small smooth colorless surface colonies on ISP2 medium. The optimum temperature and $\mathrm{pH}$ required for growth of the strain were $28^{\circ} \mathrm{C}$ and $7.5^{\circ} \mathrm{C}$, respectively. The strain showed $\mathrm{NaCl}$ tolerance up to $5 \%(\mathrm{w} / \mathrm{v})$. The physiological and biochemical characteristics of the strain are illustrated in Supplementary Table 2. The 16S rRNA was sequenced and BLAST analysis against the GenBank 


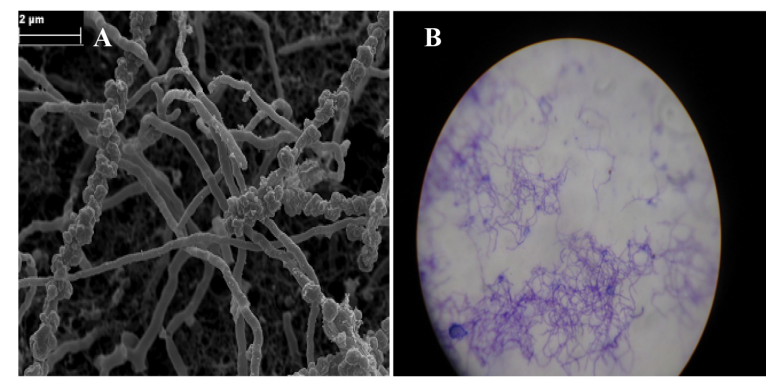

FIGURE 8 | Micro-morphological characteristic of Glycomyces sediminimaris UTMC 2460 on ISP2 medium after 10 days' incubation at $28^{\circ} \mathrm{C}$. (A) Scanning electron micrograph of spore chains of the strain (Bar, $2 \mu \mathrm{m})$. (B) Filamentous vegetative mycelia under light microscopy.

and EzBioCloud databases showed the highest similarity with Glycomyces phytohabitant (97.01\%). The sequence of its $16 \mathrm{~S}$ rRNA was deposited in the GenBank database under accession number KU1741966. The strain has been identified as a new species in the genus under the epithet of Glycomyces sediminimaris UTMC 2460, using a polyphasic assessment (Mohammadipanah et al., 2018).

\section{Characterization of the Metabolites in the Glycomyces Extract}

UHPLC-ESI-Q-TOF-MS analyses indicated that the majority of the metabolites in the Glycomyces sediminimaris UTMC 2460 extract have molecular formulae and retention times corresponding to the diketopiperazine class of natural products (Supplementary Table 3 and Supplementary Figure 5). The major constituents are proposed to be cyclo-(leucyl-prolyl) (1), cyclo-(isoleucyl-prolyl) (2), cyclo-(phenylalanyl-prolyl) (3), cyclo-(prolyl-valyl) (4), cyclo-(alanyl-leucyl) (5), cyclo-(prolyltyrosyl) (6), and cyclo-(prolyl-tryptophyl) (7), cyclo-(alanylphenylalanyl) (8), and cyclo-(leucyl-valyl) (9) (Figure 9).

\section{DISCUSSION}

The establishment of micro- and macro-organism communities either on living or non-living substrate (biofouling) generally involve a sequence of succession started by the colonization of surfaces by bacterial biofilm formation (Wahl, 1989) and macrofouler settlement is controlled by prevention of biofilm formation (Salta et al., 2013). Therefore, bacterial adhesion is probably one of the most critical steps to target in the search for an efficient antifouling. Although, the majority of commonly used anti-fouling paints are based on biocidal agents that induce general toxic responses in the marine environment associated with heavy metal toxicity and antibiotic toxicity, some natural anti-fouling compounds from diverse source have been identified (Fusetani, 2011). However, bacterial sources are preferred as their reproducible process of cultivation and scale up that ensure product supply for commercialization (Dobretsov et al., 2006; Gademann, 2007; Qian et al., 2007). Actinobacteria pose a dominant status in the production of novel bioactive compounds including antifouling agents such as lobocompactol (Cho and Kim, 2012), quercetin (Gopikrishnan et al., 2016) and diketopiperazines (Li et al., 2006).

The majority of Iran marine ecosystems are poorly explored. Until the beginning of 2018 , less than $1 \%$ of previous studies in Iran marine habit was conducted on marine bacteria and fungi and several less known/unknown taxa are still waiting to be identified (Maghsoudlou et al., 2017). For this reason, Actinobacterial strains were isolated from subtidal sediment samples of the Iranian waters in the Persian Gulf and the Gulf of Oman and their anti-adhesion activities was evaluated versus commercial and natural anti-fouling products against dominant microfouling initiator of this ecosystem.

The investigation of the structure of pioneer fouling communities on four kinds of submerged artificial substrate (wood, fiberglass, aluminum, and steel) in Oman Sea revealed different dominant species compared to the other ecosystems. Unlike other previous studies which illustrated $\gamma$-Proteobacteria such as Pseudoalteromonas, Shewanella, and Vibrio (Lee et al., 2003) predominant in marine biofilms, in this study the prevalent initial marine fouling bacteria belonged to Mesorhizobium, Kocuria, Bacillus and Psychrobacter genera in which Mesorhizobium sp. and Kocuria sp. formed strict biofilm structures in in vitro conditions and were selected as the potent microfouler strains in the complementary analysis. The composition of bacterial biofilm communities during the first stage of biofouling period, not only differs based on the seawater in which the substrata of the biofilms were submerged but also depends on the time course and surface type. Despite the isolation of Kocuria members from different marine sources Dastager et al. (2014) and Pote and Bhadekar (2014), there hasn't been any reports demonstrating the biofilm forming abilities of this genus rather than their degradation activity. Hence, this result can trigger further studies in the field of biofilm formation and quorum sensing investigations of this genus. Based on different reports, (Prasad et al., 2014; Yong and Chan, 2014), Mesorhizobium species have been isolated from seawater and natural surfaces which were immersed in the aqua environment. In addition, they found that Mesorhizobium species have the quorum sensing abilities; hence our reported data about the strict biofilm formation ability of the isolated Mesorhizobium sp. UTMC 2518 from an aluminum platform is in line with the previous report on this genus (Yong and Chan, 2014).

In this research, the criteria for selection of artificial substrates (fiberglass, steel wood, and aluminum) were based on the frequency of usage and application of materials in the marine infrastructure equipment in Persian Gulf ports provenance of Iran. As mentioned, the surface type of immersed panels in which biofilms formed on has a fundamental role in the composition and accumulation rate of bacterial communities in biofilms sampled during the first stage of biofouling. The observed data in field experiments and former studies demonstrate that surface roughness aids the physical retention of cells by enhancing adhesive contact, protecting from hydrodynamic forces, grazing activity and desiccation (Fletcher and Callow, 1992), and settling on hydrophobic compared to 
hydrophilic self-assembled monolayers in static assays is higher (Callow et al., 2000). The highest distribution rates of fouling population on different experimental panels were in the order of wood $>$ fiberglass $>$ steel $>$ aluminum which was in line with the settled diversity. Low fouling rate on steel and aluminum panels can be originated from hydrophilic properties of the panel or viable toxicity of metal surface. As a result of this, due to high amounts of fouling on the second week immersed panels, isolation of primary marine fouling bacteria from these panels was replaced by 24-h, and 72-h immersed panels were considered. Despite higher fouling rates on wood panels, a variety of initial marine biofilm forming bacteria were obtained in the following isolation order fiberglass $>$ steel $>$ aluminum $>$ wood.

In the second part of this study, in the Actinobacterial strains isolation process, modifications were applied to the isolation media to simulate oligotrophic conditions. Amongst the retrieved Actinobacteria, approximately 30\% were separated from modified HV medium (containing NSW) which was the most oligotrophic in comparison with other media. In respected studies, 1/2 GYA medium and HV-agar medium were used, respectively, for isolation of Actinobacteria from sediment and seawater samples, demonstrating the effectiveness of oligotrophic conditions in strain isolation (Gebreyohannes et al., 2013; Sharma, 2014).

Deterrence of marine fouling is linked to the control of attachment and development of microfouling communities. The inhibition of adhesion may result from two mechanisms, i.e., a specific inhibition of the adhesion process or a consequence of toxicity toward the strain(s). In the present study, the anti-microfouling activity of the ten marine Actinobacteria from deep-sea sediments of the Persian Gulf was screened through anti-attachment assay, of which the crude extract of five strains demonstrated distinct anti-adherence activity against the settlements of potent biofilm-forming bacteria. The extract from Glycomyces sediminimaris UTMC 2460 strain exhibited the adherence inhibition in range of $72-95 \%$ with no or negligible antibacterial effect on two potent fouler bacteria in the planktonic state. This indicated limited bacterial toxicity and growth inhibition activity of the extract on the dominant microflora of this ecosystem. In accordance with the present study, the anti-microfouling activity of the crude extract of Streptomyces filamentosus R1 and S. fradiae against the marine fouling bacterial strains, such as Bacillus sp., Serratia sp., and Alteromonas sp. is reported by Bavya et al. (2011) and Prakash et al. (2015), respectively. Despite the lower antibacterial effect of $G$. sediminimaris UTMC 2460 extract on the planktonic form of the microfoulers in comparison to similar aforementioned studies, its mechanism of action has the privilege to be delivered by the biofilm formation inhibition. The effect of any anti-fouling agent on the proliferation of adhered strains has the advantage of effect on planktonic cells as they will not harm the balance of the microflora in the marine habitats.

Extra polymeric substance as a crucial and integral part of a biofilm plays a pivotal role in the durability of a biofilm through the adhesion and aggregation of other microfoulers. Therefore, abating EPS production can arrest the biofilm formation which holds promise for the development of functional anti-fouling agents. It can be concluded that, the high potent anti-adherence activity of Actinobacterial extract against Kocuria sp. UTMC 2449<smiles>CC(C)CC1NC(=O)C2CCCN2C1=O</smiles><smiles>CCC(C)C1NC(=O)C2CCCN2C1=O</smiles><smiles>O=C1NC(Cc2ccccc2)C(=O)N2CCCC12</smiles><smiles>CC(C)C1NC(=O)C2CCCN2C1=O</smiles><smiles>CC(C)CC1NC(=O)C(C)NC1=O</smiles><smiles>O=C1NC(Cc2ccc(O)cc2)C(=O)N2CCCC12</smiles><smiles>O=C1NC(Cc2c[nH]c3ccccc23)C(=O)N2CCCC12</smiles><smiles>CC1NC(=O)C(Cc2ccccc2)NC1=O</smiles><smiles>CC(C)CC1NC(=O)C(C(C)C)NC1=O</smiles>

FIGURE 9 | Structure of the putative diketopiperazines identified in the extract of Glycomyces sediminimaris UTMC 2460: 2,5-diketopiperazines cyclo-(leucyl-prolyl) (1), cyclo-(isoleucyl-prolyl) (2), cyclo-(phenylalanyl-prolyl) (3), cyclo-(prolyl-valyl) (4), cyclo-(alanyl-leucyl) (5), cyclo-(prolyl-tyrosyl) (6), and cyclo-(prolyl-tryptophyl) (7), cyclo-(alanyl-phenylalanyl) (8), and cyclo-(leucyl-valyl) (9). 
and Mesorhizobium sp. UTMC 2518 biofilm can also be attributed to the considerable inhibition in EPS production.

Besides anti-microfouling efficacy, toxicity is a major concern for marine coating industry as effective marine natural compounds are sometimes as toxic as heavy metals. Thus, the toxicity profiles of the five potent anti-microfouling extracts were also determined in this study. The absence of mortality effect on the larvae of Artemia salina mitigating their ecological concern. Additionally, compared with the $\mathrm{LC}_{50}$ of tributyltin, which is generally less than $0.00001 \mu \mathrm{g} \mathrm{ml}^{-1}$, (Cardwell et al., 1999) these results indicate that these extracts are much less toxic than tributyltin. The extract of Glycomyces sediminimaris UTMC 2460 as the most effective extract on fouling inhibition of Kocuria sp. UTMC 2449 and Mesorhizobium sp. UTMC 2518, exhibit not only no toxic effect on Artemia salina but also has a negligible hemolytic activity which is an indication of acute toxicity effect. Therefore, it can be concluded that the crude extract of Glycomyces sediminimaris UTMC 2460 can be considered as an environmentally safe anti-fouling agent.

Analysis of the crude extract of from Glycomyces sediminimaris UTMC 2460 identified nine compounds corresponding to the family of diketopiperazines. Diketopiperazines are known to possess potent anti-fouling activity (Li et al., 2006; Cho et al., 2012) and the anti-fouling properties of seven of the nine diketopiperazines tentatively identified in this study have already been investigated. These include compounds $\mathbf{1}, \mathbf{3}, \mathbf{4}, \mathbf{7}$, and $\mathbf{9}$ (Li et al., 2006), and metabolites $\mathbf{5}$ and $\mathbf{8}$ (Cho et al., 2012). The anti-fouling activity of Glycomyces sediminimaris UTMC 2460 is therefore most likely attributed to the production of diketopiperazines 1-9.

\section{CONCLUSION}

The overall results of the present study clearly emphasized the strain Glycomyces sediminimaris UTMC 2460 as a competent producer of the anti-microfouling natural product and substantiated its low toxic nature. Furthermore, the physiological, molecular and chemotaxonomical analysis, allowed its introduction as a new species in Glycomyces genus called Glycomyces sediminimaris. The sufficient studies to explore the bioactivity of the Glycomyces strains have not been performed and only a single report exists on the anti-tumor and antibiotic

\section{REFERENCES}

Abarzua, S., Jakubowski, S., Eckert, S., and Fuchs, P. (1999). Biotechnological investigation for the prevention of marine biofouling II. Blue-green algae as potential producers of biogenic agents for the growth inhibition of microfouling organisms. Bot. Mar. 42, 459-465. doi: 10.1515/BOT.1999.053

Bakkiyaraj, D., and Karutha Pandian, S. T. (2010). In vitro and in vivo antibiofilm activity of a coral associated actinomycete against drug resistant Staphylococcus aureus biofilms. Biofouling 26, 711-717. doi: 10.1080/08927014.2010. 511200

Bavya, M., Mohanapriya, P., Pazhanimurugan, R., and Balagurunathan, R. (2011). Potential bioactive compound from marine actinomycetes against biofouling bacteria. IJMS 40, 578-582. activity of $G$. harbinensis secondary metabolite (Lee et al., 1986). Hence, this report adds new valuable biological activity to this genus capability and can accelerate the investigation of other novel bioactivities from this genus and the species of G. sediminimaris. Further work on the anti-microfouling activity of the putative diketopiperazines produced by G. sediminimaris and field trial experiments are demanding to development a novel eco-friendly compound that is introduced as a potential substitute for commercial chemical biocide in the maritime industry.

\section{AUTHOR CONTRIBUTIONS}

$\mathrm{SH}$ performed the experiments and analysis and wrote the draft of the manuscript. FM and AM contributed as supervisors. FM defined the approach, designed the experiments, and edited the manuscript content. AM managed the water/sediment sampling. YD and GC performed the metabolite profiling, wrote the related sections, and contributed to the editing of the manuscript. All authors read and approved the final version of the manuscript.

\section{FUNDING}

This study was partially supported by the Centre for International Scientific Studies and Collaboration, Iran and Iranian National Institute for Oceanography and Atmospheric Science (Project grant number: 393-S-011-08). The Dionex 3000RS/Bruker MaXis Impact instrument used in this study was purchased with a grant to GC from the BBSRC (Grant Reference BB/K002341/1).

\section{ACKNOWLEDGMENTS}

The authors would like to thank Dr. Vahid Sepahvand for his cooperation and helping in the sampling process.

\section{SUPPLEMENTARY MATERIAL}

The Supplementary Material for this article can be found online at: https://www.frontiersin.org/articles/10.3389/fmicb. 2018.03148/full\#supplementary-material

Bayani, N. (2016). Ecology and environmental challenges of the persian gulf. Iran. Stud. 49, 1047-1063. doi: 10.1080/00210862.2016.1241569

Callow, M. E., Callow, J., Ista, L. K., Coleman, S. E., Nolasco, A. C., and López, G. P. (2000). Use of self-assembled monolayers of different wettabilities to study surface selection and primary adhesion processes of green algal (Enteromorpha) zoospores. Appl. Environ. Microbiol. 66, 3249-3254. doi: 10.1128/AEM.66.8. 3249-3254

Cao, S., Wang, J., Chen, H., and Chen, D. (2011). Progress of marine biofouling and antifouling technologies. Chin. Sci. Bull. 56, 598-612. doi: 10.1007/s11434010-4158-4

Cardwell, R. D., Brancato, M. S., Toll, J., Deforest, D., and Tear, L. (1999). Aquatic ecological risks posed by tributyltin in United States surface waters: pre-1989 to 1996 data. Environ. Toxicol. Chem. 18, 567-577. doi: 10.1271/bbb.120221 
Chen, Y.-H., Kuo, J., Sung, P.-J., Chang, Y.-C., Lu, M.-C., Wong, T.-Y., et al. (2012). Isolation of marine bacteria with antimicrobial activities from cultured and field-collected soft corals. World J. Microbiol. Biotechnol. 28, 3269-3279. doi: 10.1007/s11274-012-1138-7

Cho, J. Y., Kang, J. Y., Hong, Y. K., Baek, H. H., Shin, H. W., and Kim, M. S. (2012). Isolation and structural determination of the antifouling diketopiperazines from marine-derived Streptomyces praecox 291-11. Biosci. Biotechnol. Biochem. 76, 1116-1121. doi: 10.1271/bbb.110943

Cho, J. Y., and Kim, M. S. (2012). Induction of antifouling diterpene production by Streptomyces cinnabarinus PK209 in co-culture with marine-derived Alteromonas sp. KNS-16. Biosci. Biotechnol. Biochem. 76, 1849-1854. doi: 10. 1271/bbb.120221

Dastager, S. G., Tang, S.-K., Srinivasan, K., Lee, J.-C., and Li, W.-J. (2014). Kocuria indica sp. nov., isolated from a sediment sample. Int. J. Syst. Evol. Microbiol. 64, 869-874. doi: 10.1099/ijs.0.052548-0

Dobretsov, S., Abed, R. M., and Teplitski, M. (2013). Mini-review: inhibition of biofouling by marine microorganisms. Biofouling 29, 423-441. doi: 10.1080/ 08927014.2013.776042

Dobretsov, S., Dahms, H.-U., and Qian, P.-Y. (2006). Inhibition of biofouling by marine microorganisms and their metabolites. Biofouling 22, 43-54. doi: 10.1080/08927010500504784

Donlan, R. M., and Costerton, J. W. (2002). Biofilms: survival mechanisms of clinically relevant microorganisms. Clin. Microbiol. Rev. 15, 167-193. doi: 10. 1128/CMR.15.2.167-193.2002

DuBois, M., Gilles, K. A., Hamilton, J. K., Rebers, P. T., and Smith, F. (1956). Colorimetric method for determination of sugars and related substances. Anal. Chem. 28, 350-356. doi: 10.1021/ac60111a017

Fletcher, R. L., and Callow, M. E. (1992). The settlement, attachment and establishment of marine algal spores. Br. Phycol. J. 27, 303-329. doi: 10.1080/ 00071619200650281

Fusetani, N. (2011). Antifouling marine natural products. Nat. Prod. Rep. 28, 400-410. doi: 10.1039/C0NP00034E

Gademann, K. (2007). Cyanobacterial natural products for the inhibition of biofilm formation and biofouling. CHIMIA Int. J. Chem. 61, 373-377. doi: 10.2533/ chimia.2007.373

Garrett, T. R., Bhakoo, M., and Zhang, Z. (2008). Bacterial adhesion and biofilms on surfaces. Prog. Nat. Sci. 18, 1049-1056. doi: 10.1016/j.pnsc.2008.04.001

Gebreyohannes, G., Moges, F., Sahile, S., and Raja, N. (2013). Isolation and characterization of potential antibiotic producing actinomycetes from water and sediments of Lake Tana, Ethiopia. Asian Pac. J. Trop. Biomed. 3, 426-435. doi: 10.1016/S2221-1691(13)60092-1

Goodfellow, M., Kämpfer, P., Busse, H.-J., Trujillo, M. E., Suzuki, K.-I., Ludwig, W., et al. (2012). Bergey's Manual of Systematic Bacteriology: The Actinobacteria, Vol. 5. New York, NY: Springer. doi: 10.1007/978-0-387-68233-4

Gopikrishnan, V., Radhakrishnan, M., Shanmugasundaram, T., Pazhanimurugan, R., and Balagurunathan, R. (2016). Antibiofouling potential of quercetin compound from marine-derived actinobacterium, Streptomyces fradiae PE7 and its characterization. Environ. Sci. Pollut. Res. Int. 23, 13832-13842. doi: 10.1007/s11356-016-6532-5

Heindl, H., Thiel, V., Wiese, J., and Imhoff, J. F. (2012). Bacterial isolates from the bryozoan Membranipora membranacea: influence of culture media on isolation and antimicrobioal activity. Int. Microbiol. 15, 17-32. doi: 10.2436/20.1501. 01.155

Hudzicki, J. (2009). Kirby-Bauer Disk Diffusion Susceptibility Test Protocol. Available at: http://www.asmscience.org/content/education/protocol/protocol. 3189\#header

Lee, M. D., Borders, D. B., Labeda, D. P., Fantini, A. A., and Testa, R. T. (1986). Preparation of Antibiotic LL-D05139 $\beta$ from Cultures of Glycomyces Harbinensis, gen. nov., sp. nov. Wayne, NJ: American Cyanamid Company.

Lee, Y. K., Kwon, K.-K., Cho, K. H., Kim, H. W., Park, J. H., and Lee, H. K. (2003). Culture and identification of bacteria from marine biofilms. J. Microbiol. 41, 183-188.

Li, X., Dobretsov, S., Xu, Y., Xiao, X., Hung, O. S., and Qian, P.-Y. (2006). Antifouling diketopiperazines produced by a deep-sea bacterium, Streptomyces fungicidicus. Biofouling 22, 187-194. doi: 10.1080/08927010600780771

Maghsoudlou, A., Momtazi, F., Nasiri, K., Pazooki, S., Molavi-Arabshahi, M., Sepahvand, V., et al. (2017). A review on the state of the biodiversity knowledge on Iran's southern seas: introducing a methodology to evaluate the validity of the reported cases. Mar. Biodivers. 1-19. doi: 10.1007/s12526-0170835-8

Maldonado, L. A., Stach, J. E., Pathom-Aree, W., Ward, A. C., Bull, A. T., and Goodfellow, M. (2005). Diversity of cultivable Actinobacteria in geographically widespread marine sediments. Antonie Van Leeuwenhoek 87, 11-18. doi: 10. 1007/s10482-004-6525-0

Meyer, B., Ferrigni, N., Putnam, J., Jacobsen, L., Nichols, D. J., and McLaughlin, J. L. (1982). Brine shrimp: a convenient general bioassay for active plant constituents. Planta Med. 45, 31-34. doi: 10.1055/s-2007971236

Mohammadipanah, F., Atasayar, E., Heidarian, S. H., and Wink, J. (2018). Glycomyces sediminimaris sp. nov., a new species of Actinobacteria isolated from marine sediment. Int. J. Syst. Evol. Microbiol. 68, 2357-2363. doi: 10.1099/ ijsem.0.002847

Padmavathi, A. R., Abinaya, B., and Pandian, S. K. (2014). Phenol, 2, 4bis (1, 1-dimethylethyl) of marine bacterial origin inhibits quorum sensing mediated biofilm formation in the uropathogen Serratia marcescens. Biofouling 30, 1111-1122. doi: 10.1080/08927014.2014. 972386

Pathom-Aree, W., Stach, J. E., Ward, A. C., Horikoshi, K., Bull, A. T., and Goodfellow, M. (2006). Diversity of actinomycetes isolated from challenger deep sediment (10,898 m) from the mariana trench. Extremophiles 10, 181-189. doi: 10.1007/s00792-005-0482-z

Piazza, V., Roussis, V., Garaventa, F., Greco, G., Smyrniotopoulos, V., Vagias, C., et al. (2011). Terpenes from the red alga Sphaerococcus coronopifolius inhibit the settlement of barnacles. Mar. Biotechnol. 13, 764-772. doi: 10.1007/s10126010-9337-4

Pote, S., and Bhadekar, R. (2014). Statistical approach for production of PUFA from Kocuria sp. BRI 35 isolated from marine water sample. BioMed Res. Int. 2014:570925. doi: 10.1155/2014/570925

Prakash, S., Ramasubburayan, R., Iyapparaj, P., Arthi, A. P. R., Ahila, N. K., Ramkumar, V.S., et al. (2015). Environmentally benign antifouling potentials of triterpene-glycosides from Streptomyces fradiae: a mangrove isolate. RSC Adv. 5, 29524-29534. doi: 10.1039/C4RA15335A

Prasad, M., Sethi, R., Anand, M., and Padmavathi, T. (2014). Degradation of agrowastes by lignocellulolytic activity of bacterial isolates from marine sources. Asian J. Plant Sci. Res. 4, 60-63.

Qian, P.-Y., Lau, S. C., Dahms, H.-U., Dobretsov, S., and Harder, T. (2007). Marine biofilms as mediators of colonization by marine macroorganisms: implications for antifouling and aquaculture. Mar. Biotechnol. 9, 399-410. doi: 10.1007/ s10126-007-9001-9

Qian, P.-Y., Xu, Y., and Fusetani, N. (2009). Natural products as antifouling compounds: recent progress and future perspectives. Biofouling 26, 223-234. doi: 10.1080/08927010903470815

Ramesh, S., and Mathivanan, N. (2009). Screening of marine actinomycetes isolated from the Bay of Bengal, India for antimicrobial activity and industrial enzymes. World J. Microbiol. Biotechnol. 25, 2103-2111. doi: 10.1007/s11274009-0113-4

Sale, P. F., Feary, D. A., Burt, J. A., Bauman, A. G., Cavalcante, G. H., Drouillard, K. G., et al. (2011). The growing need for sustainable ecological management of marine communities of the Persian Gulf. AMBIO 40, 4-17. doi: 10.1007/ s13280-010-0092-6

Salta, M., Wharton, J. A., Blache, Y., Stokes, K. R., and Briand, J. F. (2013). Marine biofilms on artificial surfaces: structure and dynamics. Environ. Microbiol. 15, 2879-2893. doi: 10.1111/1462-2920.12186

Satheesh, S., Soniamby, A., Shankar, C. S., and Punitha, S. M. J. (2012). Antifouling activities of marine bacteria associated with sponge (Sigmadocia sp.). J. Ocean Univ. China 11, 354-360. doi: 10.1007/s11802-0121927-5

Schwartz, N., Dobretsov, S., Rohde, S., and Schupp, P. J. (2017). Comparison of antifouling properties of native and invasive Sargassum (Fucales. Phaeophyceae) species. Eur. J. Phycol. 52, 116-131. doi: 10.1080/09670262.2016. 1231345

Sharma, M. (2014). Actinomycetes: source, identification, and their applications. Int. J. Curr. Microbiol. Appl. Sci. 3, 801-832.

Stackebrandt, E. (2014). "The order glycomycetales and the genus actinocatenispora," in The Prokaryotes, eds E. Rosenberg, E. F. DeLong, S. Lory, E. Stackebrandt, and F. Thompson (Berlin: Springer), 381-390. 
Staneck, J. L., and Roberts, G. D. (1974). Simplified approach to identification of aerobic actinomycetes by thin-layer chromatography. Appl. Microbiol. 28, $226-231$.

Stepanović, S., Vuković, D., Dakić, I., Savić, B., and Švabić-Vlahović, M. (2000). A modified microtiter-plate test for quantification of staphylococcal biofilm formation. J. Microbiol. Methods 40, 175-179. doi: 10.1016/S0167-7012(00) 00122-6

Subramani, R., and Aalbersberg, W. (2013). Culturable rare Actinomycetes: diversity, isolation and marine natural product discovery. Appl. Microbiol. Biotechnol. 97, 9291-9321. doi: 10.1007/s00253-013-5229-7

Thomas, K., and Brooks, S. (2010). The environmental fate and effects of antifouling paint biocides. Biofouling 26, 73-88. doi: 10.1080/08927010903 216564

Wahl, M. (1989). Marine epibiosis. I. Fouling and antifouling: some basic aspects. Mar. Ecol. Prog. Ser. 58, 175-189. doi: 10.3354/meps05 8175

Wayne, P. (2017). CLSI. Performance Standards for Antimicrobial Susceptibility Testing: CLSI Supplement M100, 27th Edn. Wayne, PA: Clinical and Laboratory Standards Institute.
Yong, P.-L., and Chan, K.-G. (2014). Quorum sensing activity of Mesorhizobium sp. F7 isolated from potable water. ScientificWorldJournal 2014:874764. doi: 10.1155/2014/874764

Yoon, S.-H., Ha, S.-M., Kwon, S., Lim, J., Kim, Y., Seo, H., et al. (2017). Introducing EzBioCloud: a taxonomically united database of $16 \mathrm{~S}$ rRNA gene sequences and whole-genome assemblies. Int. J. Syst. Evol. Microbiol. 67, 1613-1617. doi: 10.1099/ijsem.0.001755

Conflict of Interest Statement: The authors declare that the research was conducted in the absence of any commercial or financial relationships that could be construed as a potential conflict of interest.

Copyright (C) 2019 Heidarian, Mohammadipanah, Maghsoudlou, Dashti and Challis. This is an open-access article distributed under the terms of the Creative Commons Attribution License (CC BY). The use, distribution or reproduction in other forums is permitted, provided the original author(s) and the copyright owner(s) are credited and that the original publication in this journal is cited, in accordance with accepted academic practice. No use, distribution or reproduction is permitted which does not comply with these terms. 